\title{
Nada Šabec
}

University of Maribor

Faculty of Arts, Slovenia

\section{Slovene-English Language Contact and Language Change}

\section{Summary}

The paper focuses on Slovene - English language contact and the potential language change resulting from it. Both the immigrant context (the U.S. and Canada) and Slovenia, where direct and indirect language contact can be observed respectively, are examined from two perspectives: social on the one hand and linguistic on the other. In the case of Slovene Americans and Canadians the emphasis is on language maintenance and shift, and on the relationship between mother tongue preservation and ethnic awareness. The linguistic section examines different types of bilingual discourse (borrowing, code switching), showing how the Slovene inflectional system in particular is being increasingly generalized, simplified and reduced, and how Slovene word order is gradually beginning to resemble that of English. In the case of Slovenia we are witnessing an unprecedented surge in the influence of English on Slovene, especially in the media (both classic and electronic), advertising, science, and the language of the young. This influence will be discussed on a number of levels, such as lexical, syntactic and intercultural, and illustrated by relevant examples.

Key words: language contact, language change, accommodation, language shift, borrowing, code switching, identity

\section{Slovensko-angleški jezikovni stik in jezikovne spremembe}

\section{Povzetek}

Članek obravnava slovensko-angleški jezikovni stik in jezikovne spremembe, ki izhajajo iz le-tega. Pri tem gre za dve okolji, izseljenskega (ZDA, Kanada) in slovenskega. V prvem gre za neposredni jezikovni stik, v drugem za posrednega, v obeh pa pojav raziskujem tako z jezikoslovenga kot $\mathrm{z}$ družbenega vidika. V primeru ameriških in kanadskih Slovencev je poudarek na jezikovnem ohranjanju oz. jezikovnem premiku ter na odnosu med ohranjanjem maternega jezika in etnične ozaveščenosti. V jezikovnem delu se osredinjam na različne tipe dvojezičnega diskurza (sposojanje, kodno preklapljanje), pri čemer ugotavljam, da prihaja do postopnega posploševanja, poenostavljanja in opuščanja slovenskih sklanjatvenih vzorcev, medtem ko postaja slovenski besedni vrstni red v nekaterih segmentih vedno bolj podoben angleškemu. V Sloveniji smo po drugi strani priča doslej najmočnejšemu vplivu angleščine na slovenščino, predvsem v medijih (tako klasičnih in elektronskih) in v jeziku mladih. Ta vpliv analiziram na različnih jezikovnih ravninah od leksikalne do sintaktične in medkulturne ter ga ponazorim z ustreznimi primeri.

Ključne besede: jezikovni stik, jezikovne spremembe, akomodacija, jezikovni premik, sposojanje, kodno preklapljanje, identiteta 


\section{Slovene-English Language Contact and Language Change}

\section{Introduction}

Language contact is a widespread phenomenon that can be can be examined from different perspectives, including the social/functional and linguistic/structural ones. Depending on the specific circumstances in which it occurs, on the reasons for its occurrence and on the different outcomes that it may produce, it can be classified into different types. One criterion that I will rely on in my article is whether the contact is direct or indirect. Direct language contact refers to situations where "groups of people who speak very similar varieties are in contact with people who speak rather different varieties" (Thomason 2001, 2) such as immigrant situations. On the other hand, language contact may be indirect or distant (Winford 2003), where the influence of one language on the other does not occur directly, but rather through the mediation of written texts or, recently, mostly through the Internet and other electronic media, also referred to as $\mathrm{CMC}$ or computer-mediated-media. ${ }^{1}$ Regardless of the type, however, language contact may trigger varying degrees of language change. Language contact and language change are thus closely interrelated, as will be illustrated by the case of Slovene and English. I will first address the direct Slovene-English language contact in the immigrant environment of the United States and Canada, and then focus on the situation in Slovenia, where we are currently witnessing the ever stronger indirect influence of English on Slovene.

\section{Slovene-English Language Contact in an Immigrant Environment}

For obvious reasons, immigrant environments, where people speaking different languages are in contact on a daily basis, are ideally suited to the study of language contact. In my research so far I have examined several Slovene speech communities both in the United States and in Canada (Cleveland, Washington, D.C., Fontana, Toronto, Vancouver). Due to space limitations I will not be able to describe all five of them. Instead, I will focus on Cleveland, the largest Slovene American community in the U.S., where I carried out the most extensive fieldwork and, for the sake of comparison with smaller communities, also briefly present the situation in Washington, D.C.

The language contact situation will be first addressed from the social perspective in terms of language use and language attitudes and then from the structural perspective, analyzing different forms of bilingual discourse and interlingual influences. Language change will be explained both on societal and individual levels as a consequence of sociolinguistic accommodation.

\subsection{Sociolinguistic Accommodation on the Societal Level}

As a starting point I will take the definition of Giles and Coupland (1991), who explore "accommodative processes" in relation to identity, whereby speakers may manipulate language in order "to maintain integrity, distance or identity" (ibid., 66). I believe that this concept of accommodation theory, which focuses on the interactive aspects of communication and

Computer-Mediated-Media is defined as "communciation that takes place between human beings via the instrumentality of computers" (Herring 1996, 1). 
emphasizes its negotiative character, is best suited to explain the various shifts in language use that occur in the case of Slovene Americans both on individual and societal levels.

On a broader, societal level, accommodation is manifested through different stages of intergenerational language shift from Slovene to English. In order to understand this process, we need some background information on Slovene immigration to the USA.

Slovenes immigrated to the US in general and to Cleveland in particular in two major waves: at the turn of the century and after WW II. ${ }^{2}$ The early, economic immigrants had little or no education, most were illiterate and spoke only regional dialects. With no professional skills they worked in steel mills and other factories and lived in ethnically segregated neighborhoods, where they could rely on ethnic organizations and communicate in their mother tongue. These neighborhoods were so Slovene in character that the Harvard Encyclopedia of American Ethnic groups states that "In Cleveland, for example, St. Clair Avenue from 30 to East $79^{\text {th }}$ Streets became by the 1920s so completely Slovene in character that English was the foreign language" (Thernston 1980, 973). The partial influence of English was seen only in borrowing, where lexemes from the donor English language were morphologically and partly phonologically adapted to the recipient Slovene language through the attachment of Slovene suffixes to the English bases. The second generation, their children, however, having already learned English, in most cases moved out of the inner city and progressed both socially and economically. This was even more true of the third, pre-war, generation, which is mostly college educated, but no longer or only exceptionally speaks Slovene. The post-war group of immigrants came to the States primarily for political reasons; they were better educated, had a working knowledge of English and thus a much better starting position. Residential concentration was no longer essential to their survival, and the majority settled in the suburbs. Linguistically, it is interesting that they have a good command of both the dialects and Standard Slovene, which is why they only rarely resort to borrowing. Instead, they engage in code switching, which involves the alternate use of two discrete linguistic systems. Their children are similar to the third, pre-war, generation in that they speak little or no Slovene and also in terms of their social and economic mobility.

Cleveland Slovenes are known for maintaining close contact with Slovenia and supporting an impres-sive number of ethnic organizations. After the general ethnic revival in the US in the 1970s, and again after Slovenia's independence in 1991, Slovene Americans experienced a renewed interest in searching for their roots and in preserving their heritage.

Washington Slovenes, on the other hand, represent a relatively small ethnic group (a few hundred). They moved to the capital city after WW II either from Slovenia or from other US federal states. They were attracted by occupational and professional opportunities that were quite different from those of early immigrants to Cleveland. Being well-educated, the majority of Washington Slovenes work in managerial positions, in academia, as federal employees and the like. For them, living together was never a matter of survival, but rather a matter of personal choice, a way to enrich their social and cultural lives and to express their identity.

Compared to Cleveland Slovenes, they are far less heterogeneous in terms of generations. In WW II is used to divide the immigrants into two large groups: the pre-war and the post-war ones. 
fact, it only makes sense to classify them into two groups: Slovene-born and American-born, as any more detailed classifications would yield few, if any, meaningful results. Those who speak Slovene are very proficient in it (some have even published in the language). There is practically no borrowing and even code switching is relatively rare compared to Cleveland. The Sloveneborn participants are understandably better at Slovene than American-born ones, but there are a few cases where children speak very good Slovene, too. In all cases, however, the respondents are skeptical about Slovene language maintenance in the future and even though the Slovene-born respondents cite language as the most important factor in their ethnic identification, already their children do not see ethnic identity as depending primarily on the language.

The Cleveland data in particular reveal significant intergenerational variation both in the participants' bilingual competence and in their attitudes toward the two languages. While the older generations and the more recent Slovene-born immigrants still speak Slovene, the younger ones, born in the U.S., have to a great extent lost their facility in the language. The most bilingual of all is the second generation of pre-war immigrants, but their use of Slovene is confined to ethnic contexts. It is precisely because of this general perception that the Slovene language plays an important symbolic role, but has in fact very little, if any, pragmatic value, that the situation among American Slovenes is that of a very unstable, transitional bilingualism. This is best illustrated by the fact that the shift from Slovene to English among the pre-war immigrants occurred over the course of three generations, but took only two generations in the case of post-war immigrants.

Viewed from the accommodation perspective, the language shift just described could be interpreted as a form of adjustment, whereby Slovene communities experienced a kind of convergence of their language toward the dominant English and in the process also underwent certain language contact-induced changes, seen primarily in borrowing, code switching and various types of interlingual influences on different linguistic levels.

It is interesting that the partial or at times even complete language shift occurred despite the fact that, on the declarative level, the great majority of the respondents attribute a very high degree of importance to the maintenance of the mother tongue (even though they do not consider it to be the most important factor in ethnic identification - this is culture instead), and that the two communities share a very strong sense of appreciation of their ethnic heritage and a very positive self-image. The Slovene American communities are thus likely to survive even though its members may in the future no longer identify themselves as being bilingual but rather as bicultural.

A likely explanation for such a development can be found in their ambition to integrate into mainstream society as fully as possible as well as in the objective circumstances, i.e. the omnipresent, even though not overt pressure of English. The non-explicit character of the influence of English seems to be a relevant factor, as the immigrants' convergence toward English in this particular environment is in marked contrast to some other contexts, where Slovene under overt pressure has survived despite everything (e.g. during WW II, when in the occupied Slovene territories it was forbidden to speak Slovene; in 1989, when the prospect of a court trial against Slovene dissidents in Serbo-Croatian ${ }^{3}$ triggered mass demonstrations and the eventual

Serbo-Croatian was one of the three official languages in the former Yugoslavia. Although Slovene, Macedonian and Serbo-Croatian were declared to be equal, Serbo-Croatian was in fact the dominant language from the socilinguistic perspective and the only one 
disintegration of the former Yugoslavia; in present-day Austria, where members of the Slovene minority keep fighting for bilingual signs and schools).

\subsection{Sociolinguistic Accommodation in Face-to-Face Interactions}

Even more transparent forms of sociolinguistic accommodation can be observed in the face-toface interactions of the participants in the study. While their language choice understandably depends on the level of their bilingual proficiency, it is also to a large extent determined by their social and psychological motivations. In general, the interviews and the participant observation show that the subjects spoke more Slovene with those people who, in their opinion, felt more comfortable speaking Slovene (e.g. the elderly, visitors from Slovenia), and almost always switched to English when a monolingual English speaker joined in the conversation. Bilinguals therefore exhibit various degrees of linguistic intravariation in their conversations. Their choice of a particular language in any particular situation depends on the degree of intimacy or social distance that they wish to establish between themselves and their addressee. This phenomenon can be explained within the theoretical framework of the audience design (Bell 1984) and of the interpersonal accommodation theory (Giles and Johnson 1981, 1987). According to the former, speakers design their speech in such a way as to accommodate their addressees. This is done by style shifting, which in a bilingual situation translates into a choice between two codes/ languages. The accommodation is directed primarily at the addressee, but also at the so called third persons (auditors, who are present, but not directly addressed, and overhearers). Their influence is of secondary importance compared to the addressee's, but can be observed in those cases mentioned earlier, when the appearance of an English monolingual may cause the switch to English. According to the interpersonal accommodation theory, something very similar happens. The interlocutors generally adapt their speech style to each other's when there is an affinity between them and when they want to bridge the social or personal gap between them. As they expect some potential benefit from the interaction (which may be anything from possible future cooperation to simply enjoying each other's company) they attempt to move closer to each other by resorting to their shared ethnic language. By converging in this direction they reduce their dissimilarities and express a sort of mutual solidarity. The opposite may, of course, also happen when instead of convergence we observe divergence from the use of the language shared by all the participants. The purpose of such behavior is to exclude the participant/s from the conversation. This again may happen for a number of reasons. A very common one, which I did not observe, but was told about by a number of participants in this study was for the parents to speak Slovene so that the children would not understand what they were saying.

\subsection{Structural Aspects of Sociolinguistic Accommodation and Potential Language Change}

In addition to the social/functional aspects of accommodation described thus far, there are also structural dimensions to be considered. The previously mentioned forms of bilingual discourse,

used in the Army. After the disintegration of Yugoslavia and the formation of new states it split into different varieties such as Croatian, Serbian, and Montenegrin. 
borrowing and code switching, are the most obvious instances of that. In the case of borrowing we deal with the contact of English and Slovene on the level of a single word, which results in words such as kara, drajuati, zbrokan (from car, to drive and broken). The most common items that undergo this process of phonological and morphological adaptation belong to open sets of word classes (nouns, verbs, adjectives) and serve either to fill lexical gaps or are used in the case of most frequently occurring everyday words. While borrowing is typical of the early immigrants, later generations engage primarily in code switching, which involves the alternate use of two languages in the same conversation (Šabec 1995) but keeps them separate at all times. The phenomenon is rather complex, it may occur on intra- or intersentential levels, in different directions and may be subject to various syntactic constraints. A detailed analysis of these aspects would exceed the scope of this article, which is why I will only provide a few typical examples of nouns, verbs, adjectives, adverbs, numerals and discourse markers that are usually the subject of switching.

- Ko smo mi šli nazaj, business je vedno bil težek, tough, but we made it, see.

/When we returned, the business was always hard, tough, but we made it, see./

-In moj ata so prišli v Cleveland ninety twenty-one and then met and married my mother

/And my dad came to Cleveleand ninety twenty-one and then met and married my mother./

- Vsak večer špilajo kak šport, baseball, soccer, you never know when they'll be home.

/Every evening they play sports, baseball, soccer, you never know when they'll be home./

While language change in the process of borrowing and code switching is fairly salient, monolingual stretches of the immigrants' discourse in Slovene also show traces of English influence. These can be observed on various linguistic levels from phonology (aspirated plosives, rhotic $r$ etc.) to morphology and syntax. Morphology in particular, where the Slovene inflectional system is being increasingly generalized, simplified and reduced, is an important area conducive to language change. In syntax, change involves a gradual change of word order. It is occasionally more fixed, thus resembling English, or simply used at random, disregarding the rules of Slovene. The following examples show different degrees of convergence of the weaker Slovene toward the dominant English.

- Pa smo šli z moja vnuk in poli smo vzeli ena slika od cela žlahta. (wrong gender and case of the nouns, a calque to take pictures instead of the verb slikati/fotografirati)

/We went with my grandson and took a picture of the entire family.l

- Pa se moraš ustavit pri tisti lučem in se potem obrniti na desno, da prideš do tam. (wrong case of the noun luči, wrong number of the demonstrative pronoun tisti, luči instead of the Slovene equivalent semafor).

/You have to stop at those traffic lights and then turn right to get there./ 
- In ona je pela tud' ko je b’la ona mlada, samo potem ko je ona poročila, ni b’lo več časa za vaje. /redundant use of the pronoun ona, omission of the reflexive se with the verb poročiti se).

/And she also sang when she was young, but then when she got married, she no longer had time for rehearsals./

-Smo šli z moja prijateljica mož. (wrong case of the nouns and the pronoun).

/We went with my friend's husband.I

- In dokler je prišel, ni šel nobeden proč. (analogy with the English word order, where in Slovene the negative particle would be used: dokler $n i$ prišel).

IAnd until he came, nobody left.I

- Pa je mislil, da to taku živiljenje tam delal, pa ni šlo. (calque delati živiljenje instead of the verb preživljati seldelati).

/And he thought that he would make a living there, but it didn't work out./

Yet another manifestation of language change in the immigrant environment involves a partial leveling of dialects in the case of immigrants originating from different parts in Slovenia. While it is true that Cleveland Slovenes especially maintain a degree of dialect distinctiveness in their speech, this is far less pronounced than it was in the "old country."

And finally, the use of second person pronouns as terms of address may be at least partially explained as being influenced by English. While Slovene has a binary system of second person pronouns, whereby a single interlocutor can be addressed either as $t i$ or $v i$ and where the choice implies different degrees of personal and social (in)equality among speakers or, according to Brown and Gilman (1960), power and solidarity, English uses the single form you in all cases.

While in Slovenia, the distinction between $t i$ and $v i$ in addressing the other is largely observed (with the exception of some younger speakers), it is thus quite common for Slovene visitors to the States to be addressed as $t i$ by complete strangers upon first meeting them. More precisely, the pronouns often seem to be used more or less at random, but with a very strong bias in favor of $t i$. Only some older Slovene-born immigrants still observe the distinction with any consistency, while all others state their preference for $t i$. There are of course at least two other possible explanations for such attitudes and use: the exclusive use of $t i$ brought to the States by some early arrivals from the "old country,"5 and the uncertainty as to which pronoun to choose due to poor linguistic competence in Slovene. The third one, the influence of English, however, seems very likely and is confirmed by the responses provided in by the participants in the Toronto and Fontana studies. Younger speakers especially believe that the more formal $v i$ is

The name used by the immigrants to refer to Slovenia and the territories from which they had emigrated.

Ti as the only pronoun used by lower classes such as peasants. 
redundant and that the less formal, casual $t i$ better serves their needs in addressing others on an equal footing. Compared to the relatively conservative and stable $t i$ vs. vi distinction in Slovenia, Slovenes in the U.S.A. and Canada use predominantly the informal $t i$, which is in line with the dynamics in the relations between people living in a fairly egalitarian and socially mobile society. The tendency to address people by first names only underscores this finding.

\section{Slovene-English Language Contact in Slovenia}

Compared to the immigrant context, the forms of Slovene-English language contact in Slovenia are somewhat different, as are the reasons for it. The contact is indirect: in the past it used to happen through written texts and via intermediary languages such as German (e.g. the work keks from the English cake), recently it has been occurring mostly via CMC. In the past, such instances were rare; in recent decades they represent almost daily occurrences. The reasons for the extent and the speed with which English influences Slovene should no doubt be sought in the ongoing globalization processes, increasing mobility and the widespread availability of the Internet. The three are largely based on the use of English as a lingua franca of international communication, which means that all other languages, Slovene included, can hardly avoid its influence. It should be noted that the mentioned processes have also impacted upon English itself. While in the past English used to belong exclusively to native speakers, and standard varieties of, say, British and American English, served as models for non-native speakers to emulate, this is no longer always the case. Non-native speakers of English now outnumber native ones, which has resulted on the one hand in the split of English into several local varieties such as Indian English and Singapore English (so-called World Englishes), and on the other into Global English used by the Internet community. This variety, also referred to as World English, International English, Lingua Franca English, Globish, Weblish (e.g. Crystal 2001a), displays a high degree of variation depending on the varying degrees of proficiency of its users, transfers from their mother tongues, deviations from the norm, simplifications and the like, thus defying easy or even precise codification. Its users can no longer be defined in terms of traditional speech communities constrained by physical or geographical boundaries (Labov 1966; Milroy 1980), but rather as on-line communities of practice based on different professional and other interests (Lave and Wengner 1991). English in lingua franca use then has become "deterritorialized or post-geographic" variety (James 2008, 79 and passim), which "as the linguistic manifestation of a myriad of set of contexts of using, can also be seen as a - globalised and globalising - linguistic resource for intercultural communication and transcultural flows" (James 2009, 86). This aspect of English in as far as it is relevant to Slovene both socially and culturally will be discussed in more detail later. First, however, I will turn my attention to the ways in which the influence of English is felt on various linguistic levels of Slovene.

\subsection{Linguistic Influences}

These occur primarily on lexical and partly on syntactic and orthographic levels. 


\subsubsection{Vocabulary}

Since vocabulary is the part of language which is, as a rule, the most susceptible to influences from other languages it will be addressed first and in more detail than the rest. It should be noted that lexical items are not only among the most frequently borrowed ones, but also the easiest to accept by most speakers, as they generally do not disrupt the structure of the native language, but are simply inserted into it and used either in response to the need for naming new objects, concepts or inventions or for some other reasons. And it is precisely these reasons that distinguish the Slovene situation from that of Slovene Americans and Canadians. While Slovene immigrants borrow English words to fill lexical gaps (e.g. fonati from to phone; gradžuirati from to graduate), in Slovenia this is done for other reasons as well. Only some lexical items enter Slovene because the language does not possess its own words (e.g. bojkot, parkirati, golf, skenirati, lobirati; recently klikniti, guglati, tvitanje), in most other cases there already exist perfectly acceptable or established Slovene equivalents. The reasons for borrowing are thus of an essentially different nature and have to do primarily with prestige, whereby "an element is borrowed from a language which is culturally or politically dominant" (Shukla and Connor-Linton 2006, 294). The speakers presumably use them to appear more fashionable, cosmopolitan, and "in". Examples of such loanwords are marketing, consulting, hit, lider, tekst (instead of trženje, svetovanje, uspešnica, vodja, besedilo) and many others.

Depending on the age and type of borrowed words, they may develop in different directions. In the beginning they tend to be fairly unstable both in spelling and in pronunciation (e.g. leasing/lizing; in rare cases this happens also with some loanwords that have been in the language for a long time, e.g. cocktail/koktajl/koktejl)), after undergoing various degrees of phonological, morphological and orthographic adaptation, however, some may become totally integrated into Slovene and behave the same as any other Slovene word (e.g. sendvic, pullover, piknik). It is also possible for some to adopt phonologically and morphologically, but not orthographically (e.g. wellness and jacuzzi, which with their atypical spelling do indeed stand out). Borrowings or loanwords may continue to co-exist with their Slovene equivalents (e.g. resničnostni šov vs. reality show, glamur vs. blišc, laptop vs. prenosnik), in some cases they may acquire a specialized meaning, either narrower than in the original (e.g. juice, where in English this refers to all juices, in Slovene only to orange juice) or broader (e.g. toast in the sense of a ham and cheese toasted sandwich, while in English the meaning is limited to a toasted slice of bread), they may largely displace a Slovene word (stres instead of pritisk) or turn out to be short-lived and, after a while, fall into oblivion. It is worth noting that for some loanwords which had no Slovene equivalents when they were first borrowed, some very good and widely used Slovene substitutes have been created (e.g. najstnik, računalnik, tiskalnik, dlančnik from teenager, computer, printer, palm calculator; in some other cases, however, attempts to do the same were less successful, an example of which is the word spletni dnevnik for blog, where blog not only prevailed, but even gave rise to other related words such as bloganje, bloger, blogerski and the like). On the other hand, many other terms which have spread to Slovene (and many other languages) over the Internet more recently have never undergone that process precisely because of the speed with which they have "invaded" the languages; they have been accepted uncritically without due consideration of looking for suitable equivalents in the native language (e.g. stand up komik, mobbing). Yet another example of lexical influence are calques, 
some already well established ones (e.g. pranje možganov from brainwashing), some of more recent origin (e.g. mreženje from networking) and some that may not be widely understood and whose status therefore remains uncertain for the time being (e.g. "...se mi zdi na neuspeh obsojeno prizadevanje, da bi (mu) dokazali 'kadečo se pistolo'v roki" (Flegar 2009, 4) / ...I find attempts to prove that he has a smoking gun in his hand doomed from the outset./ )

Individual English loanwords and calques are used by scientists, business people and also by the general public, but nowhere do we find as much English influence as in the language of the young and in the media. The young use English as a basis for their slang, thus expressing their in-group solidarity and anti-conformist attitudes toward grown ups (e.g. ful, kul, d'best, fajt, džoint, frend, brejkič, fensi, izi, skenslati, densat, biti na badu, bajdvej, enivej, iti v lajf, in to je najbolj tekmovalna tekma ever). Slang, of course, is a rather short lived phenomenon that keeps changing with each generation, which is why the influence of English is not likely to have a lasting effect on the society as a whole. The same is true of teen magazines that often tend to imitate slang.

With other media, however, we see a real proliferation of English that may leave a more enduring mark on the language. This is true of both traditional print media and even more so of the electronic ones. The former often publish texts in which the authors insert whole phrases and sometimes even longer passages in English. Some expressions are thus written in italics, in inverted commas or even accompanied by glosses and footnotes. While realizing that such usage may strike readers as obscure, idiosyncratic or even incomprehensible, some authors nevertheless seem to take their readers' proficiency in English for granted. This is not typical only of the tabloid press, but also of more "serious" newspapers and magazines. By the same token, English is frequently used in TV programs, especially on commercial stations that are in some cases owned by American corporations. Consequently, programs catering to popular taste, including various entertainment shows, soaps operas and the like are typically globalized/Americanized.

Examples from newspapers and magazines:

- Welfare state je farewell, tisto, kar potrebujemo v 21. stoletju, je enabling state. (Mekina 2010, 43)

/Welfare state is farewell, what we need in the $21^{\text {st }}$ century is an enabling state./

- Zato upam, da se bo ta globalni trg nepremičnin čim prej sesul, do tedaj pa bi si morali prizadevati za institutionalizacijo in legalizacijo skvotinga - zasedanja takih praznih stavb. (Kučić 2010, 6)

/I thus hope that the global real estate market will collapse as soon as possible. Until then we should strive for the institutionalization and legalization of squattingtaking over of empty buildings./

- Današnje guglanje, tvitanje in fejsbukanje se bo počasi skrilo v nove oblike druženja in postalo njegov sestavni del. (Kučić 2010, 7)

/The current googling, tweeting and facebooking will gradually be subsumed into new forms of networking and become its integral part./ 
- TV (ali video) on demand (na zahtevo) sicer že nekaj časa obstaja, vendar stvar ni razvita in razširjena do te mere, da bi se otroška logika instantnega zadovoljevanja TV želja lahko uveljavila kot splošen "odrasli" način gledanja. (Crnkovič 2009, 54) ITV (or video) on demand has been around for some time now, but it has not yet developed and spread to the point where the children's logic of instant gratification of TV desires would be adopted as a universal "grown up" way of watching./

The language found on blogs, tweets (as a sort of "microblogs" or "facebooks SMS's"), forums, and other forms of CMC, on the other hand, is usually a mixture of Slovene and English with deviations in spelling, punctuation, combinations of figures and letters, acronyms, word plays and other features typical of netspeak (Šabec 2009). There are also Slovene bloggers who write exclusively in English, which is in most cases a variety of Global English as defined at the beginning of this article. The following example illustrates nicely the described situation.

- F.R.I.E.N.D.S. in "zobke umit pa spat" no more

Kdo jih ne pozna. Okej, bom polinkal.

Ampak - počasi gledam vse sezone, starting with numero 1.

Yep, well, I've done that one. Zdej sem v drugi, ko Ross in Rachel...umgh!

A ste bli vi tudi slučajno stari cca. 10 let (+/- 2 leti), gotta leave some room for standard error) in so bili F.r.i.e.n.d.s.i na TV-ju? Ob $R E S^{*}$ poznih urah?? No, well, jaz sem bil. And it sucked. Zakaj, pobarate? No, ker pač nisem mogel gledat frendsov. Pa še prestavljali so jih. Enkrat so bili ob 23.30. Uuuurgggh! Ampak zdej...zdej lahko gledam anytime I want. Ker so a) na netu in b) na prenosnem disku. In c) so izpiti. Damn. No, ampak d) sej človk rabi malce odmora, taku, možganskega anede? In se ne more učit čist $C E L$ dan.

Kakorkoli, hotel sem samo napisati ene dve fori iz tega dela, ki je ravno in progress (you try to be awake a week in a row till 4 a.m., studying incredibly interesting facts of life, such as biology and co. offers).

Ross: "Rachel and Julie...that's the problem."

Joey: "HEY! I've got two words for you: threesome!"

...

Chandler: "You still got one left, you know."

//Monica: "OK, this is pumpkin pie,.../.../ Mochocolate chip cookies, Mochocolate strawberry cake,.... Taste it!"

Rachel: "OMG!"

Monica: "OMG good?"

R: "OMG I can't believe you let me put this into my mouth!"

Phoebe: "Sweet LORD! Ugh! This is what EVIL must taste like."

...:)

*Really back then meant 22.30./ (http://aljobaljo.blogspot.com)

/F.R.I.E.N.D.S. and "brush your teeth and off to bed" no more

Who doesn't know them? Okay, I'll check the link 
But - I'm slowly going through all the seasons, starting with number $1 . .$. Yep, well, I've done that one. Now I'm on the second one, when Ross and Rachel.... umgh!

Were you also about ten years old ( $+/-2$ years, gotta leave some room for standard error) when F.r.i.e.nd.s. was on TV? REALLY* late? Ok, well, I was. And it sucked. Why, you may ask? Well, because I was not allowed to watch the friends. And they kept changing the time. Once they were on at 23.30. Uuurgggh!

But now...now I can watch anytime I want. Because they are a) on the net and b) on portable disk and c) it's the exam time. Damn. Well, but d) a guy needs some time off, to rest one's brain, right? and e) and cannot study ALL day long.

Anyway, I just wanted to write about one or two little gems from this episode, which is now in progress (you try to be awake in a row till $4 \mathrm{a}$ a.m., studying incredibly interesting facts of life, such as biology and co. offers):

Ross: "Rachel and Julie...that's the problem."

Joey: "HEY! I've got two words for you: threesome!"

$\ldots$

Chandler: "You still got one left, you know."

//Monica: "OK, this is pumpkin pie,.../.../ Mochocolate chip cookies, Mochocolate strawberry cake,.... Taste it!"

Rachel: "OMG!"

Monica: "OMG good?"

R: "OMG I can't believe you let me put this into my mouth!"

Phoebe: "Sweet LORD! Ugh! This is what EVIL must taste like."

...:)

*Really back then meant 22.30./

Finally, I cite some examples in which the media go too far in its eagerness to copy everything English, showing their ignorance in both their mother tongue and in English, as well as, in my opinion, a lack of respect for their readership.

- Leve vlade so privatizacijo velikih državnih podjetij in prodajo blue chipov bolj ali manj zadrževale. (Lorenci 2009, 15)

/Leftist governments are trying to privatize state-owned companies and to stall with selling of blue chips./

- Staroselec na področju odnosov z javnostmi, z občasnimi izleti na področje advertisinga. (Magdalenc 2010, 26)

/An old hand at PR, with the occasional excursion into the field of advertising./

- Se mi zdi kul, da kljub skrajno angažiranemu govorjenju o vseh okoli nas na koncu vedno ostanejo na površini kakšne domislice. Tudi v obliki gossipov. (Magdalenc 2010, 24)

/I think it is cool that despite extremely engaged talk about everybody around us in 
the end some smart ideas always surface. Also in the form of gossip./

- Drugi pa je, da je naša šola na napačnih točkah odprta do pritiska staršev, in to tistih, ki se gredo nekaj, čemur pravijo Angleži overparenting, prekomerno starševanje. (Snežič 2009, 15)

/Another thing is that our school is too susceptible to pressure from parents who practice something referred to as overparenting by the English./

- Samo za orientacijo, kakšna naj bo javna RTV? Ali naj vključuje visoko gledane entertaining oddaje, kot je na primer Piramida? (Škrinjar and Kolšek 2009, 5)

/Just to get things straight, what should public radio and TV look like? Should it include entertaining programs with high ratings such as Piramida?/

- Sky is the limit! Meja je nebo. Pa še uživati je treba zraven. (Luzar 2008, 20) /Sky is the limit! And you should enjoy, too./

\subsubsection{Syntactic Influences}

Compared to the huge influx of English lexical items into Slovene, the impact of English on Slovene syntax seems almost negligible. It is certainly less visible and more subtle, at times even difficult to detect. Occasionally, however, we come across strange sounding structures which, on closer examination, reveal that their "creators" simply took a short cut and transferred them to Slovene directly from English.

- Če vas zanima glasba, vas enkrat več vabimo k poslušanju. (an invitation to listeners on Radio City; this one heard on 18.4. 2010 at 11.15)

/If you are interested in music, we invite you to tune in one more time./

Enkrat več, heard several times on Radio City, seems to be used on the analogy of the English once morelone more time instead of the Slovene še enkrat/ponouno.

- “...si je privoščil...nekoliko grobo opazko na račun Van Rompuya, češ da ima karizmo kot vlažna cunja...” (Škrinjar 2010, 1)

I....he went as far as using... a somewhat rude remark at the expense of Van Rompuy, saying that he has the charisma of a wet blanket./

To be a wet blanket is an English idiom, used figuratively and referring to a person who is not much fun and cannot be translated literally into Slovene.

- Bil je ime, znano vsem gospodinjstvom v ZDA. (Žigon 2009, 43)

/He was a household name in the U.S.A./

An English fixed phrase to be a household name translated literally into Slovene sounds awkward and should have been translated as popularen/slaven, i.e. popular/famous.

The copy-paste approach clearly speaks of the sloppiness and linguistic incompetence of their authors. 
Another, more transparent case of English influence on Slovene word order, however, is the increase in the use of the noun+noun combinations typical of English instead of the Slovene adjective+noun structures or other types of nominal phrases.

- Anti-stress program v našem wellness centru /anti-stress program in our wellness center/

- Anti-age posegi obraza in telesa (anti-age treatment for face and body)

- Cellfood kartica ugodnostiv izbranih lekarnah/cellfood loyalty/benefit card in selected pharmacies/

- City Center/Magazine

- UVA zašcita /UVA protection/

- Izobraževanje TOP strokovnjakov leducation of TOP experts/

- Kako prideš do brezplačne čokolade? 1. Postani oboževalec (fan) Gorenjke. 2. Pridruži se Gorenjka čokoman klubu. /How to get a free chocolate bar? Become a Gorenjka fan. 2. Join the Gorenjka chocoman club./

The pattern has become quite common and many no longer see it as being foreign to the spirit of the Slovene language. Yet another aspect involves the excessive use of possessive pronouns, for instance with body parts, a feature typical of English, but not of Slovene.

- Potem, ko ste pripravljeni dvignite vaše roke do vašega čela v gassho položaj. (whttp:// www.tomazflegar.si)

/After you are ready, please raise your hand up to your forehead and put into the gashho position/

As pointed out, syntactic influences may not seem very obvious and are far less numerous than lexical ones, but they affect the structure of the language in much more profound ways than mere loanwords, which is why they have far more serious implications in terms of language change.

\subsubsection{Orthographic Influences}

Orthographic influences of English on Slovene have attracted practically no attention by researchers so far. I nevertheless see them as important because of their potentially long-term effect on the future development of Slovene. I have in mind especially young Slovenes, who have not had sufficient exposure to the orthographic norm of Standard Slovene and may find themselves simply copying what they see on the Internet or on billboards. These two (the Internet and advertising) are in fact the two areas that represent the richest source of data for anybody interested in the influence of English on Slovene orthography. In CMC as well as in short messages we find anything from the use of English characters that do not exist in Slovene $(x, y, w, q)$ to the replacement of Slovene characters by English ones ( $c, s, z, s$ instead of $\dot{c}, \dot{s}, \check{z} ; c / c h$ instead of $k, x$ instead of $k s$ ), from the doubling of consonants and vowels $(s s, o o)$ to the lack of punctuation or incorrect use of it (O'glasna pošta, Hobby \& Art, Odvetniki Šelih \& Partnerji, Rože 
$\& v r t$ ), from English acronyms to a variety of combinations of figures and letters and to other forms of creative spelling.

- Dobro, pis of kejk je bilo rešiti tole. /Good, it was a piece of cake to solve this./

- Zakaj bi komplicirali...če je življenje lahko SIMPL? /Why complicate if life can be simple?/

- Dogfrisbee 4 fun tekma, sobota, 15.8.2009. /Dogfrisbee for fun contest, Saturday, 15.8. 2009./

- Itaq, ex(xtra), exspress, pravi boom na finančnem trgu /a real boom on the financial market/

- $\quad$ odrej (Andrej)

Similarly, advertising relies heavily on English-like spelling conventions. Various features from word play to simply including English letters are used to attract consumers' attention and make their products more appealing. The same is true of many companies, bands and artists who, by choosing English (brand) names or at least adapting them to English spelling, apparently feel more "in" and, by projecting the impression of being more creative, aim at reaching wider audiences.

Similarly, advertising relies heavily on English-like spelling conventions. Various features from word play to simply including English letters are used to attract consumers' attention and make their products more appealing. The same is true of many companies, bands and artists who, by choosing English (brand) names, apparently feel more "in" and, by projecting the impression of being more creative, aim at reaching wider audiences.

- /WO-HO! Clio has been entertaining us for twenty years./6 (a car advertisement)

- My Way poletne počitnice po vašem okusu (Kompas MY WAY programi) /My Way summer holidays according to your taste; Kompas MY WAY programs/ (a tourist agency advertisement)

- Anything you need. Baby, you got it, anything you want, you got it (Merkur advertisement)

- Jesenski EGO SLIM \& VITAL (a yogurt advertisement)

- RE.ST - reciklirani stoli /recycled chairs/

- $\quad$ FRUC - totalno kul, totalno old school. /FRUC . totally cool, totally old school/ (a soft drink advertisement)

Interjections are an intriguing part of language as they express emotions and may thus be indicative of deeper links between the users' language choice and their identification with a certain language and the related culture. In this case the interjection is not Slovene. Similar examples include the more and more widely used oops, ouch and wow. 
- MEGA factory Outlet

- THE be the best (T.HE. d.o.o.) - revija o treningu in športni prehrani. Ob naročilu dobite brezplačno darilo THE VITaMIN. /THE be the best (T.H.E. d.o.o. a magazine on sports practice training and foods. Upon subscribing you will receive our free gift THE VITaMIN.I

- Smuthies: energy/relax/antistress (a yogurt/smoothie advertisement by Ljubljanske mlekarne)

- Maxximum Shop, Merkur Group, Mercator, Dental Art, d.o.o.

- Alya, Neisha, Slon 'n' Sadež (names of pop artists and bands)

\section{Social and Cultural Influences}

The already discussed influence of English on advertising is just one part of a wider scene that exceeds strictly linguistic boundaries. It is part of broader phenomena that, with the increasing adoption of globalized/Americanized discourse patterns, seemingly friendly, but fundamentally more aggressive advertising, sensationalist tabloid-style approaches to writing, the popularization of various reality shows, infotainment programs and the like, affect the social and cultural character of Slovenia. Analyzing all of its forms in detail would require an article in its own right. For the purpose of this survey, however, I will focus on yet another socio-cultural dimension of the influence of English that has to do with the expression of identity through language. Language and culture are very closely interlinked and language choice, when applicable, is very telling in as far as personal, social, cultural and any other identity of the speaker is concerned. In a recent study of language choice in Slovene blogs, I found that many Slovene bloggers have moved away from the exclusive use of Slovene. Instead they use either (Global) English or a mixture of Slovene and English (referred to as Sloglish in my previous work; Šabec 2009). Their choice can be interpreted from two perspectives: social and cultural.

Socially, a choice by an individual is indicative of his or her desire to belong to an on-line community that also uses English and is in this sense more "in" than those who do not. They therefore share the code/language that they perceive as more prestigious. At the same time the kind of language that they use is sufficiently different from standard forms of English and Slovene; this therefore bonds them together in a sort of in-group solidarity, which has parallels in the way slang is normally used.

From a cultural perspective the choice of language is further motivated by psychological reasons. We can assume that in a code switching/mixing situation the language of choice is the one that the speakers feel most comfortable using in a particular situation. From this perspective it is interesting that many Slovene bloggers choose English for their (nick)names, blog titles and blog entries. The fact that the Internet allows its users communication under multiple/fake/deceptive and other kinds of identities that they can choose at will, and that in addition most function under the impression that they are anonymous, their choices are even more revealing. They are 
free to use their imagination and to express their innermost feelings in any way they like. The fact that some often do it in English may reflect their more pragmatic ambitions to reach out to a wider network of potential "friends" and become part of the global virtual community. The dilemma between the local and the global is clearly visible, which no doubt has important cultural and social implications, also in terms of opening up new ways of (inter)cultural communication.

- Blog titles: so long sweet summer; Just the usual life; JeRNej's digital life; Fejker.net; Jackie4grace; Rat-ON-crack; ...pieces of me...; C.C.P.cre@ions; Wild@heart: Wilma on green plant; Lance's corner; Another day in a geek's life; Way wrong way; It's a big world out there: Almost pure blue sky....almost; I'm good, I'm gone; I'm back (on track); life sucks when things don't go the way you want, sweet sorrow; Simon says

- $\quad$ Nick(names) in blogs and tweets: angryguy; i-love-emo; blackflower: just.crazy; punchka:bjutiful; Junior; Lance Vance; Majchek, UrSha

It should be noted that blogs and tweets are not the only areas where this phenomenon can be observed. As an example I cite the newsletter of the University of Maribor's medical students' association, whose title is INSAJDER, and last, but not least, a not negligible number of parents who choose English or more "internationally sounding" names for their newborns (e.g. Jason, Vanessa, Timothy, Amber, Damyan, Nikol, Tifani).

\section{Conclusion}

This article is an attempt at presenting Slovene-English language contact in its many forms and contexts and from different perspectives. As a result, it inevitably falls somewhat short of providing an in-depth analysis of a larger number of relevant examples. Instead it aims at providing a more comprehensive picture of the phenomenon in the hope of drawing attention to its widespread occurrence and the implications that it has for language change. Language change is something that happens all the time. It can be studied diachronically or as an ongoing process. In both cases it is the one area that offers most valuable insights into the dynamics of language change and innovation. In the case of Slovene-English language contact, it naturally also poses the question of a balance between the imports from English and the (un)critical attitudes toward them, the question of the status of Slovene in the Slovene media, and of the benefit of taking from English in order to enrich the Slovene language by augmenting its flexibility and expressiveness on the one hand and on the other of the potential detrimental effect on it when done to excess. Describing the current state of affairs and predicting possible directions in which the two languages in contact might develop in the future makes contact linguistics a highly relevant and intriguing field of study and represents a challenge for further research.

\section{Bibliography:}

Bell, A. 1984. Language Style as Audience Design. Language in Society 13, no. 2: 145-204.

Brown, R., and A. Gilman. 1960. The Pronouns of Power and Solidarity. In Style in Language, ed. T.A. Sebeok, 253-76. Cambridge: MIT Press. 
Crystal, D. 2001a. English as a Global Language. Cambridge: Cambridge University Press.

- - -. 2001b. Language and the Internet. Cambridge: Cambridge University Press.

Giles, H., and P. Johnson. 1981. The Role of Language in Ethnic Group Relations. In Intergroup Behaviour, ed. J.C. Turner and H. Giles, 199-243. 0xford: Blackwell.

- - -. 1987. Ethnolinguistic Identity Theory: A Social Psychological Approach to Language Maintenance. International Journal of the Sociology of Language 68: 69-99.

Giles, H., and N. Coupland. 1991. Language: Contexts and Consequences. Keynes: Open University Press.

Herring, S. 1996. Computer-Mediated-Communication: Linguistic, Social and Cross-Cultural Perspectives. Amsterdam: Benjamins.

James, A. 2008. New Englishes as Post-geographic Englishes in Lingua Franca Use: Gender, Interdiscursivity and Later Modernity. European Journal of English Studies 12, no. 1: 97-112.

- - -. 2009. Theorising English and Globalisation: Semiodiversity and Linguistic Structure in Global English, World Englishes and Lingua Franca English. Apples - Journal of Applied Language Studies 3, no. 1: 79-92.

Kingsley, B., and B.B. Kachru, eds. 2006. World Englishes: Critical Concepts in Linguistics. London and New York: Routledge.

Lave. J., and E. Wengner. 1991. Situated Learning: Legitimate Peripheral Participation. Cambridge: Cambridge University Press.

Labov, W. 1966. The Social Stratification of English in New York City. Washington, DC: Center for Applied Linguistics.

McArthur, T. 2002. The Oxford Guide to World English. Oxford: Oxford University Press.

Milroy, L. 1980. Language and Social Networks. Oxford: Basil Blackwell Publisher.

Phillipson, R. 1992. Linguistic Imperialism. Oxford: Oxford University Press.

Shukla, S., and J. Connor-Linton. 2006. Language Change. In An Introduction to Language and Lingusitics, ed. R. Fasold and J. Connor-Linton, 275-310. Cambridge, New York, Melbourne, Cape Town, Singapore, Sao Paulo: Cambridge University Press.

Stramljič Breznik, I. 2007. Slovenska slengovska frazeologija danes. Slovenski jezik - Slovene Linguistic Studies 6: 183-93.

Šabec, N. 1995. Half pa pu: The Language of Slovene Americans. Ljubljana: ŠKUC, Studia Humanitatis.

- - -. 1997. Slovene-English language contact in the USA. International Journal of the Sociology of Language 124 (Sociolinguistics of Slovene): 129-83.

- - -. 2002. Second Person Pronouns Used by Slovene and American Sovene Speakers as Linguistic Markers of Personal and Social (In)equality. Acta Neophilologica 35, no. 1/2: 115-26.

- - -. 2006. Language, Society and Culture: Slovene in Contact with English. Slavistična revija (Slovensko jezikoslovje danes/ Slovene Linguistics Today. Special issue, ed. A. Vidovič Muha.) 54: 703-18.

- - -. 2009. Sloglish or the Mixing/ Switching of Slovene and English in Slovene Blogs. Slavia Centralis II, no.1: 32-43.

Thernstorn, S., ed. 1980. Harvard Encyclopedia of American Ethnic Groups. Cambridge, Mass.: Harvard University Press.

Thomason, S.G. 2001. Langauge Contact. Edinburgh: Edinburgh University Press.

Žigon, P. 2009. 0.J. Simpson, najbolj kriv med vsemi nedolžnimi. Obrazi 28, 9 July, 43.

Winford, D. 2003. An Introduction to Contact Linguistics. Oxford: Blackwells.

Weinreich, U. 1953. Languages in Contact: Findings and Problems. New York: Linguistic Circle of New York. The Hague: Mouton. 


\section{Data Sources}

Crnkovič, M. 2009. Velika integracija in konvergenca. www.zurnal24.si (print edition), 19 September, 54.

Flegar, V. 2009. Rekli so: "Kadeča se pištola". Večer, 25 November, 4.

http://aljobaljo.blogspot.com (accessed 20 June 2010)

http://www.siblogs.com (accessed 9 February 2010)

http://www.tomazflegar.si (accessed 12 March 2010)

Kučić, J.L. 2010. Greet Lovink, raziskovalec spletnih družbenih forumov. Nepremičnine lahko tudi za dvajset let določijo vašo poklicno in ustvarjalno pot. Delo, Sobotna priloga, 5 June, 6.

- - -. Greet Lovink, raziskovalec spletnih družbenih forumov. Današnje guglanje, tvitanje in fejsbukanje se bo počasi skrilo v nove oblike druženja in postalo njegov sestavni del. Delo, Sobotna priloga, 5 June, 7.

Lorenci, J. 2009. Prepuščati dobra podjetja lastnikom iz tujine prostovoljno brez potrebe je norost brez primere. Mladina 31,31 July, 15.

Mekina, B. 2010. Intervju: Gregor Golobič, minister in prenovitelj. Mladina 21, May 28, 15.

Luzar, M. 2008. Dnevnik: Vse je mogoče, vse dosegljivo. Meja je Nebo. Delo, Sobotna priloga, 28 June, 20.

Magdalenc, L. 2010. Dovolj materiala za roman., Sobotna priloga, 13 Delo, March, 24.

- - -. 2010. Slovenski trenutek časa: totalna vlada neokusa in kiča. Delo, Sobotna priloga, 20 March, 26.

Snežič, J. 2009. Šolsko polje branimo tudi pred plenilci (intervju z Igorjem Lukšičem). Večer, 29 August, 15.

Škrinjar, K., and P. Kolšek. 2009. Nacionalna RTV bo (p)ostala javna (intervju z Majdo Širca). De/o, Sobotna priloga, 29 August, 20.

Škrinjar, K. 2010. Okrvavljenih nog čez prve ovire. Delo, Sobotna priloga, 6 March, 1. 